\title{
Inhibition Kinetics of Acetylcholinesterase and Phosphatases by the Active Constituents of Terminalia arjuna and Tamarindus indi- $c a$ in the Cerebral Ganglion of Lymnaea acuminata
}

\author{
Neelam Soni, Dinesh Kumar Singh, Vinay Kumar Singh*
}

Neelam Soni, Dinesh Kumar Singh, Vinay Kumar Singh*

Department of Zoology, Malacology laboratory, DDU Gorakhpur University

Gorakhpur 273009

Uttar Pradesh, India

\section{Correspondence}

Vinay Kumar Singh,

Department of Zoology, DDU Gorakhpur University Gorakhpur 273009 (U.P.), India Mobile- +919415855488; 9807110100

E-mail: vinaygkpuniv@gmail.com

\section{History}

- Submission Date: 29-11-2016;

- Review completed: 08-12-2016;

- Accepted Date: 13-12-2016.

DOI : 10.5530/pj.2017.2.25

Article Available online

http://www.phcogj.com/v9/i2

\section{Copyright}

(C) 2017 Phcog.Net. This is an openaccess article distributed under the terms of the Creative Commons Attribution 4.0 International license.

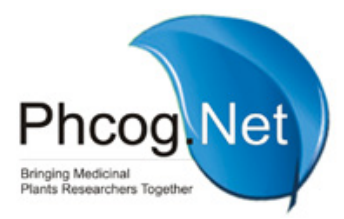

\begin{abstract}
Introduction: Paper demonstrates effect of the active molluscicidal components arjunolic acid (Terminalia arjuna bark) and procynadine (Tamarindus indica seed) on the activity of acetylcholinesterase (AChE) and phosphatases (ACP/ALP) in the cerebral ganglion of snail Lymnaea acuminata. Materials and Methods: Kinetics of AChE/ACP/ ALP inhibition in the cerebral ganglion of snail Lymnaea acuminata was studied via in vivo $(40 \%$ and $80 \%$ of 96 $\mathrm{h} \mathrm{LC}$ 50 and in vitro treatments $(0.3 \mu \mathrm{g}$ to $7.0 \mu \mathrm{g})$ of the column purified fractions, arjunolic acid and procynadine. Results: In vivo exposure of procynadine and arjunolic acid significantly inhibit acetylcholinesterase (AChE), acid phosphatase (ACP) and alkaline phosphatase (ALP) activities in the cerebral ganglion of $L$. acuminata exposed to $80 \%$ of $96 \mathrm{LC}_{50}$. In in vitro treatment maximum inhibition in AChE/ACP/ALP activities in the cerebral ganglion of snail were noted when exposed to $7.0 \mu \mathrm{g}$ of arjunolic acid and $0.9 \mu \mathrm{g}$ of procynadine. Column purified fraction of $T$. arjuna bark and $T$. indica seed caused non-competitive and uncompetitive inhibition of AChE activity, respectively. Column purified fraction and arjunolic acid of $T$. arjuna bark caused uncompetitive inhibition of ACP while column purified fraction and procynadine of $T$. indica seed caused competitive inhibition. Competitivenon-competitive inhibition of ALP activity in the cerebral ganglion of $L$. acuminata was observed after treatment of column purified active components of both plants. Conclusions: The molluscicidal activity of $T$. arjuna bark (arjunolic acid) and T. indica seed (procynadine) against snail L. acuminata is due to the inhibition of AChE/ACP/ ALP. Their inhibition kinetics against AChE/ACP/ALP, were different in cerebral ganglion of snail.
\end{abstract}

Key words: Enzymes, Lymnaea acuminata, Terminalia arjuna, Tamarindus indica, Arjunolic acid, Procynadine.

\section{INTRODUCTION}

Fasciolosis is a serious infectious parasitic disease of domestic ruminants and human worldwide. ${ }^{1,2}$ In tropical countries fasciolosis is frequently referred as the second most important parasitic disease after malaria and third most prevalent parasitic disease in the world in the terms of socio-economic and public health. ${ }^{3}$ Trematode of genus Fasciola; namely Fasciola hepatica and F. gigantica ${ }^{4,5}$ are the causative agent of fasciolosis. ${ }^{6}$ About 250 million sheep and 300 million cattle are potentially affected by the fasciolosis world-wide. ${ }^{7}$ Over the past three decade fasciolosis is recognized as an important emerging zoonotic disease of human and categorized as neglected tropical disease (NTD). ${ }^{8}$ The incidence of human fasciolosis has also been reported in different state of India. ${ }^{9}$ Life cycle of these trematodes involve snail Lymnaea acuminata as intermediate host. ${ }^{10}$ One solution to tackle the problem of fasciolosis is to destroy the carrier snail, which is an essential link in the life cycle of liver flukes. The use of synthetic or plant molluscicides is the best method of snail control. ${ }^{11,12}$ Synthetic molluscicides have created serious environmental hazards arising from contamination of ecosystem and its toxicity to non-target animals. Alternatively, molluscicides activity of plant origin are gaining more acceptance among farmers, as it is ecologically and culturally more acceptable than their synthetic counterpart. ${ }^{13,14,15}$ It has been reported that plant of Terminalia arjuna and Tamarindus indica are the potent molluscicides against the snail I. exustus. ${ }^{15}$

The present work was aimed to study the inhibition kinetics of active molluscicidal components of both plants on AChE/ACP/ALP in the cerebral ganglion of the snail Lymnaea acuminata which will expose the mode of action of both plants in the snail body.

\section{MATERIALS AND METHOD}

\section{Test materials}

Fresh stem of T. arjuna bark (Voucher specimen no. \# 3840) and T. indica (Voucher specimen no. 5648) seed were collected locally from Botanical garden of University campus. The specimens were identified and authenticated by Rtd. Prof. S. K. Singh, Taxonomist, Department of Botany, DDU Gorakhpur University, Gorakhpur, U.P. India.

\section{Column purified fraction}

$50 \mathrm{ml}$ ethanol extract of powder stem bark T. arju$n a$ and seed of T. indica were subjected to silica gel 
(60-120) mesh (Qualigens Fine Chemicals, Mumbai, India) chromatography through $95 \times 45 \mathrm{~cm}$ column. Five milliliters fractions of elutents were eluted with $95 \%$ ethanol for each column preparation. Ethanol was evaporated under vacuum and the remaining solids obtained from all 5 $\mathrm{ml}$ elutents were used for experimental analysis.

\section{Active components}

Arjunolic (2,3,23-Trihydrooxyolean-12-en, 28-oic acid) and Procynadine (cis,trans"-4,8"-Bi-(3,3,4,5,7-Pentahydroxyflavane) were parched from Sigma Chemical Co. U.S.A.

\section{Test animal}

Adult Lymnaea acuminata $(2.35 \pm 0.30 \mathrm{~cm}$ in length) were collected locally from fresh water pond and pools of Gorakhpur, Uttar Pradesh, India. Snails were acclimatized for $72 \mathrm{~h}$ in laboratory condition in dechlorinated tap water at $24 \pm 1^{\circ} \mathrm{C}$.

\section{Bioassay}

\section{In vivo treatments}

Twenty experimental snails were kept in 31 of dechlorinated tap water. Each treatment $40 \%$ and $80 \%$ of $96 \mathrm{hC}_{50}$ for $24 \mathrm{~h}$ and $96 \mathrm{~h}$ exposure of column purified fraction T. arjuna bark and T. indica seed and their active component arjunolic acid and procynadine were made, respectively (Table.1). Control group contained only 20 snails in equal volume of dechlorinated tap water without treatment. After $24 \mathrm{~h}$ and $96 \mathrm{~h}$ of the treatments snail were washed with water and the cerebral ganglion was quickly taken out for the measurement of various enzyme activity. Cerebral ganglion was removed and place in an ice cube. Afterwards, the cerebral ganglion was placed on filter paper to remove the adherent water and weight. Enzyme activity was performed in treated as well as in control group of test animal. In withdrawal experiments the snail were transferred from $24 \mathrm{~h}$ exposure of $80 \%$ of $96 \mathrm{~h} \mathrm{LC}_{50}$ of different active components in to the freshwater then after $96 \mathrm{~h}$ of enzyme assays were estimated (Table 1).

\section{In vitro treatments}

In in vitro treatments, column purified fraction and active molluscicidal component of T. arjuna bark and T. indica seed viz- arjunolic acid and procynadine, respectively were dissolve in ether and appropriate volume containing $1,3,5$, and $7 \mu$ g of column purified fraction and active component arjunolic acid and 0.3, 0.50 .7 and $0.9 \mu \mathrm{g}$ of column purified fraction and active component procynadine were added to $10 \mathrm{~mm}$ path length cuvette. The ether was then allowed to evaporate. Each molluscicide was pre-incubated for 15 minute at $25^{\circ} \mathrm{C}$ with enzyme source and the enzyme activity was determined. The control treatment contains ether only.

Michaelis-Menten constant $\left(\mathrm{K}_{\mathrm{m}}\right)$ and maximum velocity $\left(\mathrm{V}_{\max }\right)$ were calculated by plotting Lineweaver-Burk plots for the hydrolysis of different concentration of substrate by the treated $(5 \mu \mathrm{g})$ of T. arjuna bark (column purified fraction ((CPF) and arjunolic acid, and $0.7 \mu \mathrm{g}$ of T. indica seed (column purified fraction (CPF) and procynadine) and untreated enzyme.

\section{Acetylcholinesterase}

Method of Ellman et $a^{16}$ was used for the measurement of AChE in the nervous tissue of treated snail. Cerebral ganglion (50 milligram) of Lymnaea acuminata was homogenized in $1.0 \mathrm{~mL}$ of $0.1 \mathrm{M}$ phosphate buffer $\mathrm{pH} 8.0$ for 5 minutes in an ice bath then centrifuged at $1000 \mathrm{~g}$ for 30 minutes at $4{ }^{\circ} \mathrm{C}$. The supernatant was taken as an enzyme source. Incubation mixture consisting of $0.1 \mathrm{~mL}$ of enzyme source, $2.9 \mathrm{ml}$ of $0.1 \mathrm{M}$ buffer $\mathrm{pH}$ 8.0, $0.1 \mathrm{ml}$ of DTNB (5,5-dithio-bis-2-nitrobenzoic acid), and $0.02 \mathrm{~mL}$ (ATChI) acetylthiocholine iodide, solution in distilled water was used in the measurement of AChE activity. The change in optical density of incubation mixture at $412 \mathrm{~nm}$ was noted for 3 minutes after every 30 second at $25^{\circ} \mathrm{C}$. Enzyme activity has been expressed as $\mu$ mole "SH" hydrolyzed $\mathrm{min} / \mathrm{mg}$ protein. For the estimation of kinetics constant $\left(\mathrm{K}_{\mathrm{m}}\right)$ and maximum velocity $\left(\mathrm{V}_{\max }\right)$ of AChE in vitro experiment $3.0 \times 10^{-4}$, $5.0 \times 10^{-4}, 7.0 \times 10^{-4}, 1.0 \times 10^{-3} \mathrm{M}$ of substrate acetylthiocholine iodide (ATChI) was used.

\section{Acid Phosphatase}

Acid phosphatase activity was determined by the method of Bergmeyer ${ }^{17}$ as modified by Singh and Agarwal. ${ }^{18}$ Two per cent (w/v) homogenates of cerebral ganglion of snail L. acuminata was made in ice cold $0.9 \%$ $\mathrm{NaCl}$. Thereafter, homogenate was centrifuged at 5000rpm for $15 \mathrm{~min}$ utes at $4^{\circ} \mathrm{C}$. $0.2 \mathrm{~mL}$ supernatant (enzyme source) was added to $1.0 \mathrm{~mL}$ of acid buffer subtract (prepared by dissolving $0.41 \mathrm{~g}$ citric acid, $1.125 \mathrm{~g}$ sodium citrate, and $165 \mathrm{mg} 4$-nitrophenyl phosphatase sodium salt were dissolved in $100 \mathrm{~mL}$ of double distilled water) pre-incubated at $37^{\circ} \mathrm{C}$ for 10 minute. The incubation mixture was mixed thoroughly and incubated for 30 minute at $37^{\circ} \mathrm{C} .4 .0 \mathrm{~mL}$ of $0.1 \mathrm{~N} \mathrm{NaOH}$ was then added to the incubation mixture. The yellow color developed due to the formation of 4-nitrophenol. Optical density was estimated by spectrophotometer at $420 \mathrm{~nm}$. The activity of ACP is expressed as $\mu$ mole subtracts hydrolyzed/30 min/mg protein. Determination of kinetic constant $\left(\mathrm{K}_{\mathrm{m}}\right)$ and maximum velocity $\left(\mathrm{V}_{\max }\right)$ of acid phosphatase, in vitro was done by studying enzyme activity at different concentration $\left(1.25 \times 10^{-5}, 1.8 \times 10^{-}\right.$ ${ }^{5}, 3.0 \times 10^{-5}$, and $5.4 \times 10^{-5} \mathrm{M}$ ) of subtract p- nitrophenyl phosphate.

\section{Alkaline phosphatase}

Alkaline phosphatase activity in the cerebral ganglion of Lymnaea acuminata was measured by the method of Bergmeyer ${ }^{17}$ as modified by Singh and Agarwal $^{18}$. Tissue homogenate $(2 \% \mathrm{w} / \mathrm{v})$ was prepared in ice cold $0.9 \% \mathrm{NaCl}$ and determined at $5000 \mathrm{~g}$ for 15 minute at $4^{\circ} \mathrm{C}$. The supernatant was used as enzyme source 0.1 of enzyme $0.1 \mathrm{~mL}$ of enzyme source was added to $1.0 \mathrm{~mL}$ of alkaline buffer subtract (prepared by dissolving $375 \mathrm{mg}$ glycine, $10 \mathrm{mg} \mathrm{MgCl} .6 \mathrm{H}_{2} 0,165 \mathrm{mg}$ 4-nitrophenol phosphate sodium salt in $42 \mathrm{~mL}$ of $0.1 \mathrm{~N} \mathrm{NaOH}$ and a mixture was made up to $100 \mathrm{~mL}$ with double distilled water) for $30 \mathrm{~min}$ at 37 . Thoroughly mixed incubation mixture was incubated for 30 minute at $37^{\circ} \mathrm{C} .10 \mathrm{~mL}$ of $0.02 \mathrm{~N} \mathrm{NaOH}$ was then added to the incubation mixture. The yellow colour, developed due to the formation of 4-nitrophenol. The optical density was measured at $420 \mathrm{~nm}$. Activity of ALP is expressed as $\mu$ mole subtracts hydrolyzed/30 $\mathrm{min} / \mathrm{mg}$ protein in the supernatant. Determination of kinetic constant $\left(\mathrm{K}_{\mathrm{m}}\right)$ and maximum velocity $\left(\mathrm{V}_{\max }\right)$ of alkaline phosphatase was done by studying enzyme activity at different concentration $\left(1.25 \times 10^{-5}, 1.8 \times 10^{-}\right.$ ${ }^{5}, 3.0 \times 10^{-5}$, and $5.4 \times 10^{-5} \mathrm{M}$ ) of subtract $\mathrm{p}$ - nitro phenyl phosphate.

\section{Protein}

Protein was estimated in the enzyme source supernatant by the method of Lowry et al. ${ }^{19}$

\section{Statistical analysis}

Each experimental was replicated at least six times and results were expressed as mean \pm SE of Six replicates. Student's test was applied between control and treated groups to locate significant $(\mathrm{p}<0.05)$ variations. ${ }^{20}$

\section{RESULTS}

\section{In vivo enzyme inhibition}

In vivo sublethal ( $40 \%$ and $80 \%$ of $96 \mathrm{~h} \mathrm{LC}_{50}$ for $24 \mathrm{~h}$ and $96 \mathrm{~h}$ exposure) treatment of T. arjuna and T. indica seed column purified fraction and its active component arjunolic acid and procynadine caused significant 
$(\mathrm{p}<0.05)$ inhibition in AChE, ACP and ALP activities in the cerebral ganglion of Lymnaea acuminata (Table 2 and 3). Maximum inhibition of AChE activity (52.84\% of control) was observed in $80 \%$ of $96 \mathrm{LC}_{50}$ of active component procynadine while in ACP activity maximum inhibition $\left(34.66 \%\right.$ of control) was observed in $80 \%$ of $96 \mathrm{hC}_{50}$ of active component arjunolic acid. Maximum ALP inhibition (24.01\% of control) was observed in $80 \%$ of $96 \mathrm{~h} \mathrm{LC}_{50}$ of active component arjunolic acid in the cerebral ganglion of snail L. acuminata.

Significant $(\mathrm{p}<0.05)$ recovery in AChE, ACP and ALP activity was observed in the cerebral ganglion of L. acuminata withdrawn from treatment. Maximum recovery in AChE (94.79\% of control), ACP ( $82.13 \%$ of control) and ALP (89.65\% of control) were noted in the cerebral ganglion

\begin{tabular}{|c|c|c|c|}
\hline Treatment & Concentration of $96 \mathrm{~h} \mathrm{LC}_{50}$ & $40 \%$ of $96 \mathrm{~h} \mathrm{LC}_{50}$ & $80 \%$ of $96 \mathrm{~h} \mathrm{LC}_{50}$ \\
\hline T. arjuna bark CPF & $3.21 \mathrm{mg} / \mathrm{L}$ & $1.28 \mathrm{mg} / \mathrm{L}$ & $2.56 \mathrm{mg} / \mathrm{L}$ \\
\hline Arjunolic acid & $1.30 \mathrm{mg} / \mathrm{L}$ & $0.53 \mathrm{mg} / \mathrm{L}$ & $1.06 \mathrm{mg} / \mathrm{L}$ \\
\hline T. indica seed CPF & $0.71 \mathrm{mg} / \mathrm{L}$ & $0.28 \mathrm{mg} / \mathrm{L}$ & $0.56 \mathrm{mg} / \mathrm{L}$ \\
\hline Procynadine & $0.31 \mathrm{mg} / \mathrm{L}$ & $0.12 \mathrm{mg} / \mathrm{L}$ & $0.24 \mathrm{mg} / \mathrm{L}$ \\
\hline
\end{tabular}

Table 2: In vivo effect of sublethal treatments of Column purified fraction and active components of $T$. arjuna bark and T. indica seed on AChE, ACP/ ALP activity in the cerebral ganglion of $L$. acuminata.

\begin{tabular}{|c|c|c|c|c|c|}
\hline Enzyme activity & \multicolumn{3}{|c|}{ AChE ( $\mu$ mole"SH" hydrolyzed/min/mg protein) } & \multicolumn{2}{|c|}{$\begin{array}{c}\text { Withdrawal of } 80 \% \text { of } 96 \mathrm{~h} \text { LC50 after } 96 \mathrm{~h} \\
\text { treatment }\end{array}$} \\
\hline Control & \multicolumn{3}{|c|}{$0.668 \pm 0.008(100)$} & \multicolumn{2}{|c|}{$0.653 \pm 0.008(100)$} \\
\hline \multirow[t]{2}{*}{ Treatment } & \multicolumn{2}{|c|}{$24 \mathrm{~h}$} & \multicolumn{2}{|c|}{$96 \mathrm{~h}$} & \\
\hline & $40 \%$ of $96 \mathrm{~h}$ LC50 & $80 \%$ of $96 \mathrm{~h}$ LC50 & $40 \%$ of $96 \mathrm{~h}$ LC50 & $80 \%$ of $96 \mathrm{~h} \mathrm{LC50}$ & \\
\hline $\begin{array}{l}\text { T. arjuna } \\
\text { bark CPF }\end{array}$ & $0.546 \pm 0.001^{\star}(81.73)$ & $0.469 \pm 0.003^{*}(70.20)$ & $0.453 \pm 0.003^{*}(67.81)$ & $0.382 \pm 0.009^{*}(57.18)$ & $0.619 \pm 0.004^{*}(94.79)$ \\
\hline $\begin{array}{l}\text { Arjunolic } \\
\text { acid }\end{array}$ & $0.606 \pm 0.003^{*}(90.71)$ & $0.533 \pm 0.006^{*}(86.52)$ & $0.528 \pm 0.004^{*}(79.04)$ & $0.402 \pm 0.002^{*}(60.17)$ & $0.580 \pm 0.002^{*}(88.82)$ \\
\hline $\begin{array}{l}\text { T. indica } \\
\text { seed CPF }\end{array}$ & $0.580 \pm 0.002^{*}(86.82)$ & $0.511 \pm 0.003^{*}(76.49)$ & $0.425 \pm 0.003^{*}(63.62)$ & $0.399 \pm 0.003^{*}(59.73)$ & $0.536 \pm .007^{*}(82.02)$ \\
\hline Procynadine & $0.474 \pm 0.002^{*}(70.75)$ & $0.416 \pm 0.002^{*}(62.27)$ & $0.416 \pm 0.003^{*}(62.27)$ & $0.351 \pm 0.002^{*}(52.84)$ & $0.567 \pm .001^{*}(86.83 \%)$ \\
\hline $\begin{array}{l}\text { Enzyme } \\
\text { activity }\end{array}$ & \multicolumn{4}{|c|}{ ACP ( $\mu$ mole substrate hydrolyzed $/ 30 \mathrm{~min} / \mathrm{mg}$ protein) } & \\
\hline Control & & $20.22 \pm 0.05(100)$ & & & $19.59 \pm 0.03(100)$ \\
\hline \multirow[t]{2}{*}{ Treatment } & \multicolumn{2}{|c|}{$24 \mathrm{~h}$} & \multicolumn{2}{|c|}{$96 \mathrm{~h}$} & \\
\hline & $40 \%$ of $96 \mathrm{~h}$ LC50 & $80 \%$ of $96 \mathrm{~h}$ LC50 & $40 \%$ of $96 \mathrm{~h}$ LC50 & $80 \%$ of $96 \mathrm{~h}$ LC50 & \\
\hline $\begin{array}{l}\text { T. arjuna } \\
\text { bark CPF }\end{array}$ & $15.61 \pm 0.06^{*}(77.20)$ & $12.68 \pm 0.03^{*}(62.71)$ & $9.20 \pm 0.04^{\star}(40.04)$ & $7.59 \pm 0.02 *(37.53)$ & $16.09 \pm 0.01^{*}(82.13)$ \\
\hline $\begin{array}{l}\text { Arjunolic } \\
\text { acid }\end{array}$ & $17.44 \pm 0.04^{*}(76.25)$ & $12.46 \pm 0.06^{*}(61.62)$ & $8.35 \pm 0.02^{*}(41.29)$ & $7.01 \pm 0.02 *(34.66)$ & $14.49 \pm 0.04^{\star}(73.76)$ \\
\hline $\begin{array}{l}\text { T. indica } \\
\text { seed CPF }\end{array}$ & $17.47 \pm 0.04^{*}(86.31)$ & $15.01 \pm 0.04^{*}(74.23)$ & $13.14 \pm 0.4^{*}(64.98)$ & $10.25 \pm 0.04^{*}(50.69)$ & $14.63 \pm 0.03^{*}(74.68)$ \\
\hline Procynadine & $14.81 \pm 0.02^{*}(73.29)$ & $12.42 \pm 0.06^{*}(61.42)$ & $11.58 \pm 0.05^{\star}(57.27)$ & $8.97 \pm 0.02 *(44.36)$ & $13.72 \pm 0.02^{\star}(70.03)$ \\
\hline Enzyme activity & & ( $\mu$ mole substrate hyd & $\mathrm{ed} / 30 \mathrm{~min} / \mathrm{mg}$ protein) & & \\
\hline Control & & $18.11 \pm 0$ & 100) & & $18.56 \pm 0.03(100)$ \\
\hline \multirow[t]{2}{*}{ Treatment } & \multicolumn{2}{|c|}{$24 \mathrm{~h}$} & \multicolumn{2}{|c|}{$96 \mathrm{~h}$} & \\
\hline & $40 \%$ of $96 \mathrm{~h}$ LC50 & $80 \%$ of $96 \mathrm{~h}$ LC50 & $40 \%$ of $96 \mathrm{~h}$ LC50 & $80 \%$ of $96 \mathrm{~h}$ LC50 & \\
\hline $\begin{array}{l}\text { T. arjuna bark } \\
\text { CPF }\end{array}$ & $14.68 \pm 0.02^{*}(81.66)$ & $11.55 \pm 0.06^{*}(63.73)$ & $7.65 \pm 0.05^{\star}(42.24)$ & $6.67 \pm 0.06^{*}(36.83)$ & $16.64 \pm 0.07^{\star}(89.65)$ \\
\hline Arjunolic acid & $12.93 \pm 0.04^{*}(71.31)$ & $10.07 \pm 0.04^{\star}(55.60)$ & $5.54 \pm 0.03^{\star}(30.59)$ & $4.35 \pm 0.03^{\star}(24.01)$ & $14.13 \pm 0.01^{\star}(76.13)$ \\
\hline T. indica seed CPF & $15.74 \pm 0.03^{\star}(86.91)$ & $10.21 \pm 0.04^{\star}(56.73)$ & $11.80 \pm 0.02^{\star}(61.65)$ & $9.32 \pm 0.07^{\star}(51.46)$ & $15.12 \pm 0.04^{\star}(81.86)$ \\
\hline Procynadine & $13.52 \pm 0.09^{*}(74.65)$ & $11.60 \pm 0.04^{*}(64.05)$ & $10.18 \pm .01^{*}(56.21)$ & $8.87 \pm 0.03^{*}(48.97)$ & $14.28 \pm 0.07^{*}(76.93)$ \\
\hline
\end{tabular}

Values are mean \pm SE of Six replicates. Values in parentheses indicate percent enzyme activity with control taken as $100 \%$. Concentrations (W/V) have been expressed as final concentration in aquarium water. $\mathrm{CPF}$ (column purified fraction). ${ }^{*}$ - Significant $(\mathrm{P}<0.05)$ when student's $\mathrm{t}$-test was applied between treated and control groups. 
of snail withdrawn from $24 \mathrm{~h}$ treatment of $80 \%$ of $96 \mathrm{~h} \mathrm{LC} \mathrm{L}_{50}$ of T. arjuna bark column purified fraction for next $96 \mathrm{~h}$ of treatments (Table 1,2).

\section{In vitro enzyme inhibition}

In vitro pre-incubation of $7 \mu \mathrm{g}$ of column purified fraction $(67.00 \%$ of control) and arjunolic acid (69.75\% of control) of T. arjuna bark significantly inhibits the AChE activity (Table 3 ). Treatment of $0.9 \mu \mathrm{g}$ of column purified fraction $(66.39 \%$ of control) and procynadine $(62.60 \%$ of control) of T. indica seed decreased the AChE activity respectively (Table 3). Pre incubation treatment of $7.0 \mu \mathrm{g}$ of column purified fraction and arjunolic acid of T. arjuna bark decreased the ACP activity to $46.08 \%$ and $39.13 \%$ of control, respectively (Table 3 ). Treatment of $0.9 \mu \mathrm{g}$ of column purified fraction (51.21\% of control) and procynadine $(45.16 \%$ of control) of T. indica seed decreased the ACP activity respectively. In vitro treatment of $0.7 \mu \mathrm{g}$ of column purified fraction and active component (arjunolic acid) of T. arjuna bark decreased the ALP activity to $38.30 \%$ and $30.13 \%$ of control respectively (Table 3 ). Treatment of $0.9 \mu \mathrm{g}$ of column purified fraction and active component (procynadine) of T. indica seed decreased the ALP activity to $42.54 \%$ and $39.50 \%$ of control, respectively.

Line weaver-Burk plot of column purified fraction and active components shows inhibited and uninhibited enzyme activity at different substrate concentration. The plot shows that $\mathrm{K}_{\mathrm{m}}$ and $\mathrm{V}_{\max }$ of uninhibited AChE $\left(6.73 \times 10^{-3} \mathrm{M}\right.$ and $0.94 \mu$ mole "SH" hydrolyzed $/ \mathrm{min} / \mathrm{mg}$ protein),
ACP $\left(1.42 \times 10^{-5} \mathrm{M}\right.$ and $28.57 \mu$ mole substrate hydrolyzed $/ 30 \mathrm{~min} / \mathrm{mg}$ protein) ALP were, $\left(2.02 \times 10^{-5} \mathrm{M}\right.$ and $24.39 \mu$ mole substrate hydrolyzed/ $30 \mathrm{~min} / \mathrm{mg}$ protein) respectively (Table 4 ; FigURE $1,2,3$ ). $\mathrm{K}_{\mathrm{m}}$ of column purified fraction and arjunolic acid of T. arjuna inhibited AChE activity were $6.73 \times 10^{-3} \mathrm{M}$ and $6.72 \times 10^{-3} \mathrm{M}$, respectively. $\mathrm{V}_{\max }$ of column purified fraction and arjunolic acid of T. arjuna inhibited AChE activity 0.57 and $0.60 \mu$ mole "SH" hydrolyzed/min/mg protein respectively (Table 4; Figure 1 to 6). $\mathrm{K}_{\mathrm{m}}$ and $\mathrm{V}_{\max }$ value of inhibited AChE by column purified fraction and procynadine of $T$. indica seed were $5.94 \times 10^{-3} \mathrm{M}$ and $0.80 \mu$ mole "SH" hydrolyzed $/ \mathrm{min} / \mathrm{mg}$ protein (Fig 1) and $6.35 \times 10^{-3} \mathrm{M}$ and $0.81 \mu \mathrm{mole}$ "SH" hydrolyzed $/ \mathrm{min} / \mathrm{mg}$ protein respectively (Fig 2). $\mathrm{K}_{\mathrm{m}}$ and $\mathrm{V}_{\max }$ value of inhibited ACP by column purified fraction and arjunolic acid $1.40 \times 10^{-5} \mathrm{M}$ and $25.00 \mu$ mole substrate hydrolyzed $/ 30 \mathrm{~min} / \mathrm{mg}$ protein and $1.40 \times 10^{-5} \mathrm{M}$ and $25.00 \mu$ mole substrate hydrolyzed $/ 30 \mathrm{~min} / \mathrm{mg}$ protein respectively, (Fig3). $\mathrm{K}_{\mathrm{m}}$ and $\mathrm{V}_{\max }$ value of inhibited ACP column purified fraction and procynadine of $T$. indica seed were $2.31 \times 10^{-5} \mathrm{M}$ and $28.57 \mu \mathrm{mole}$ substrate hydrolyzed $/ 30 \mathrm{~min} / \mathrm{mg}$ protein, $2.48 \times 10^{-5} \mathrm{M}$ and $28.57 \mu$ mole substrate hydrolyzed $/ 30 \mathrm{~min} / \mathrm{mg}$ protein respectively (Fig 4). Kinetics of inhibition of by column purified fraction and arjunolic acid show $\mathrm{K}_{\mathrm{m}}$ and $\mathrm{V}_{\max }$ value of inhibited ALP were $2.38 \times 10^{-5} \mathrm{M}$ and $22.22,2.83 \times 10^{-5} \mathrm{M}$ and $22.22 \mu$ mole substrate hydrolyzed $/ 30 \mathrm{~min} / \mathrm{mg}$ protein respectively (Fig 5). $\mathrm{K}_{\mathrm{m}}$ and $\mathrm{V}_{\max }$ value of inhibited ALP column purified fraction and procynadine of $T$. indica seed were $2.27 \times 10^{-5} \mathrm{M}$ and $22.72 \mu \mathrm{mole}$ substrate hydrolyzed $/ 30 \mathrm{~min} / \mathrm{mg}$ protein, $2.83 \times 10^{-5} \mathrm{M}$ and

Table 3: In vitro effect of sublethal treatments of column purified fraction and active components of T. arjuna bark and T. indica seed on AChE, ACP and ALP activity in the cerebral ganglion of Lymnaea acuminata.

\begin{tabular}{|c|c|c|c|c|}
\hline Enzyme activity & \multicolumn{4}{|c|}{ AChE ( $\mu$ mole"SH" hydrolyzed/min/mg protein) } \\
\hline Control & \multicolumn{4}{|c|}{$0.668 \pm 0.008(100)$} \\
\hline Treatment & $1 \mu \mathrm{g}$ & $3 \mu \mathrm{g}$ & $5 \mu \mathrm{g}$ & $7 \mu \mathrm{g}$ \\
\hline T. arjuna bark $\mathrm{CPF}$ & $0.541 \pm 0.005(89.12)$ & $0.498 \pm 0.0003(82.04)$ & $0.469 \pm 0.0001(77.26)$ & $0.407 \pm 0.0004(67.00)$ \\
\hline Arjunolic acid & $0.566 \pm 0.001(93.24)$ & $0.521 \pm 0.0002(85.8)$ & $0.464 \pm 0.001(76.44)$ & $0.421 \pm 0.001(69.35)$ \\
\hline Treatment & $0.3 \mu \mathrm{g}$ & $0.5 \mu \mathrm{g}$ & $0.7 \mu \mathrm{g}$ & $0.9 \mu \mathrm{g}$ \\
\hline T. indica seed CPF & $0.519 \pm 0.001(85.50)$ & $0.489 \pm 0.001(80.56)$ & $0.408 \pm 0.002(67.21)$ & $0.403 \pm 0.001(66.39)$ \\
\hline Procynadine & $0.514 \pm 0.001(84.67)$ & $0.480 \pm 0.001(79.01)$ & $0.458 \pm 0.008(75.54)$ & $0.380 \pm 0.004(62.60)$ \\
\hline Enzyme activity & \multicolumn{4}{|c|}{ ACP ( $\mu$ mole substrate hydrolyzed $/ 30 \mathrm{~min} / \mathrm{mg}$ protein) } \\
\hline Control & \multicolumn{4}{|c|}{$22.59 \pm 0.01(100)$} \\
\hline Treatment & $1 \mu \mathrm{g}$ & $3 \mu \mathrm{g}$ & $5 \mu g$ & $7 \mu \mathrm{g}$ \\
\hline T. arjuna bark $\mathrm{CPF}$ & $17.18 \pm 0.06(78.12)$ & $15.62 \pm 0.02(69.14)$ & $13.71 \pm 0.02(60.69)$ & $10.41 \pm 0.09(46.08)$ \\
\hline Arjunolic acid & $16.77 \pm 0.02(74.23)$ & $14.64 \pm 0.02(64.80)$ & $12.35 \pm 0.01(54.67)$ & $8.84 \pm 0.04(39.13)$ \\
\hline Treatment & $0.3 \mu \mathrm{g}$ & $0.5 \mu \mathrm{g}$ & $0.7 \mu \mathrm{g}$ & $0.9 \mu \mathrm{g}$ \\
\hline T. indica seed CPF & $19.00 \pm 0.07(84.10)$ & $17.82 \pm 0.02(78.88)$ & $14.02 \pm 0.02(62.06)$ & $11.57 \pm 0.03(51.21)$ \\
\hline Procynadine & $18.51 \pm 0.03(82.97)$ & $16.43 \pm 0.03(72.73)$ & $14.17 \pm 0.05(62.62)$ & $10.36 \pm 0.03(45.86)$ \\
\hline Enzyme activity & \multicolumn{4}{|c|}{ ALP ( $\mu$ mole substrate hydrolyzed $/ 30 \mathrm{~min} / \mathrm{mg}$ protein) } \\
\hline Control & \multicolumn{4}{|c|}{$18.11 \pm 0.07(100)$} \\
\hline Treatment & $1 \mu \mathrm{g}$ & $3 \mu \mathrm{g}$ & $5 \mu \mathrm{g}$ & $7 \mu \mathrm{g}$ \\
\hline T. arjuna bark CPF & $17.46 \pm 0.01(78.12)$ & $13.80 \pm 0.01(61.60)$ & $10.33 \pm 0.07(46.11)$ & $8.58 \pm 0.02(38.30)$ \\
\hline Arjunolic acid & $17.05 \pm 0.04(76.05)$ & $11.77 \pm 0.03(52.54)$ & $9.67 \pm 0.01(43.16)$ & $6.75 \pm 0.01(30.13)$ \\
\hline Treatment & $1 \mu \mathrm{g}$ & $3 \mu \mathrm{g}$ & $5 \mu \mathrm{g}$ & $7 \mu \mathrm{g}$ \\
\hline T. indica seed CPF & $16.88 \pm 0.02(75.55)$ & $14.48 \pm 0.07(64.64)$ & $12.77 \pm 0.08(57.00)$ & $9.53 \pm 0.03(42.54)$ \\
\hline Procynadine & $15.64 \pm 0.04(69.82)$ & $13.23 \pm 0.02(59.06)$ & $10.56 \pm 0.05(47.14)$ & $8.85 \pm 0.03(39.50)$ \\
\hline
\end{tabular}

Values are mean \pm SE of Six replicates. Values in parentheses indicate percent enzyme activity with control taken as $100 \%$. Concentrations $(\mathrm{W} / \mathrm{V})$ have been expressed as final concentration in the incubation mixture present in cuvette. CPF (column purified fraction). ${ }^{*}$ Significant $(\mathrm{P}<0.05)$ when student's t-test was applied between treated and control groups. 
Table 4: Kinetics constant $\left(\mathrm{K}_{\mathrm{m}}\right.$ and $\left.\mathrm{V}_{\max }\right)$ of in vitro enzyme inhibition by $T$. arjuna bark (CPF) and arjunolic acid (5.0 $\left.\mu \mathrm{g}\right)$ and $T$. indica seed (CPF) and procynadine $(0.7 \mu \mathrm{g})$ in snail Lymnaea acuminata

\begin{tabular}{|c|c|c|c|c|c|c|}
\hline \multirow[t]{2}{*}{ Treatments } & \multicolumn{2}{|c|}{ Acetylcholinesterase } & \multicolumn{2}{|c|}{ Acid phosphatase } & \multicolumn{2}{|c|}{ Alkaline phosphatase } \\
\hline & $\mathrm{K}_{\mathrm{m}}(\mathrm{M})$ & $\mathrm{V}_{\max }$ & $\mathrm{K}_{\mathrm{m}}(\mathrm{M})$ & $\mathrm{V}_{\max }$ & $\mathrm{K}_{\mathrm{m}}(\mathrm{M})$ & $\mathrm{V}_{\max }$ \\
\hline Control & $6.73 \times 10-3$ & 0.94 & $1.42 \times 10-5$ & 28.57 & $2.02 \times 10-5$ & 24.39 \\
\hline $\begin{array}{l}\text { T. arjuna bark } \\
\text { (CPF) }\end{array}$ & $6.73 \times 10-3$ & 0.58 & $1.40 \times 10-5$ & 25.00 & $2.38 \times 10-5$ & 22.22 \\
\hline Arjunolic acid & $6.72 \times 10-3$ & 0.60 & $1.40 \times 10-5$ & 25.00 & $2.83 \times 10-5$ & 22.22 \\
\hline T. indica seed (CPF) & $5.94 \times 10-3$ & 0.80 & $2.31 \times 10-5$ & 28.57 & $2.27 \times 10-5$ & 22.72 \\
\hline Procynadine & $6.35 \times 10-3$ & 0.81 & $2.48 \times 10-5$ & 28.57 & $2.83 \times 10-5$ & 23.25 \\
\hline
\end{tabular}

Michaelis-Menten constant $\mathrm{K}_{\mathrm{m}}$ and $\mathrm{V}_{\text {max }}$ of different enzyme were calculated from Lineweaver-burk plots (1/V versus1/S).

Control
col. Puri

$\Delta$ arjunolic acid

\section{Non competitive inhibition of $\mathrm{AChE}$}

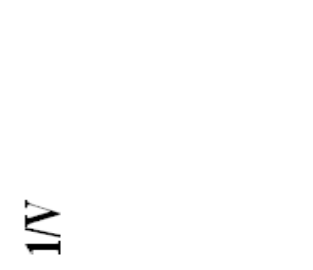

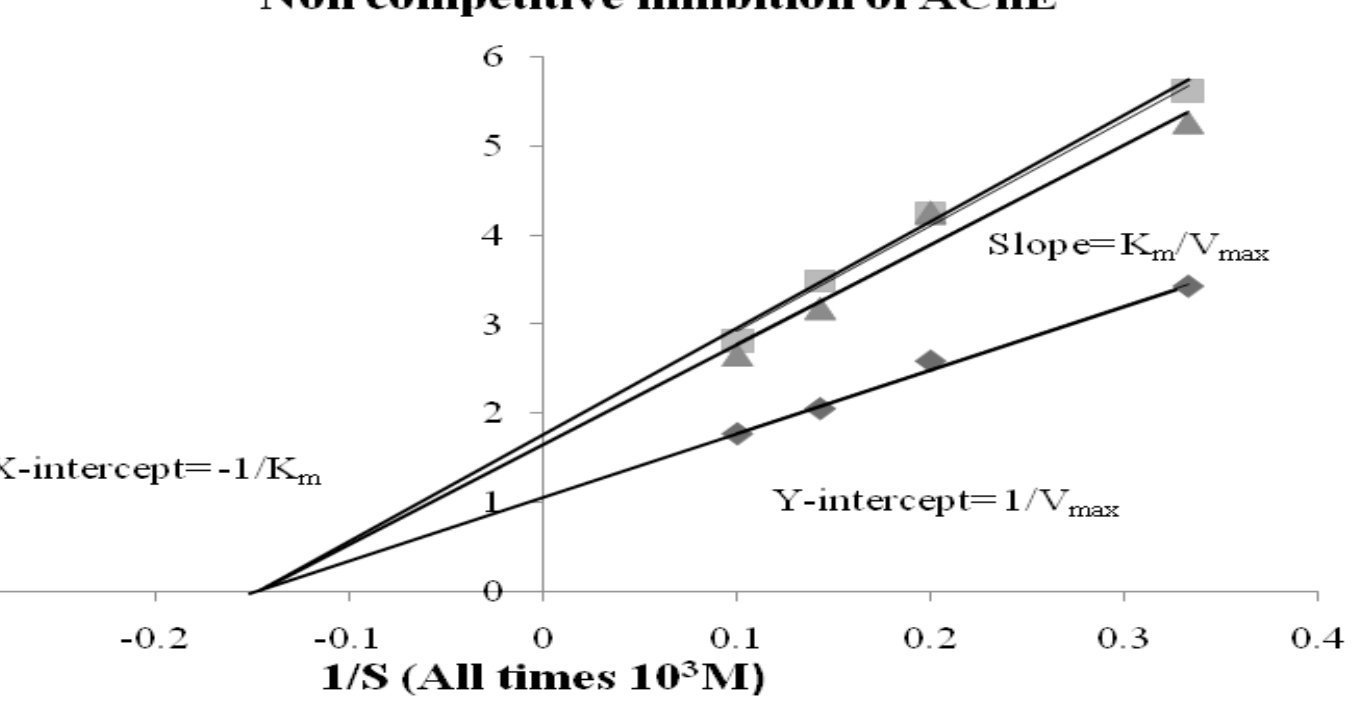

Figure 1: Line weaver-burk plots showing the effects of column purified fraction and active component arjunolic acid of T. arjuna bark (5.0 $\mu$ g) on the inhibition of acetylcholinesterase (AChE) activity in the cerebral ganglion of snail L. acuminata.

Control

A Procynadine

\section{Uncompetitive inhibition of $\mathrm{AChE}$}

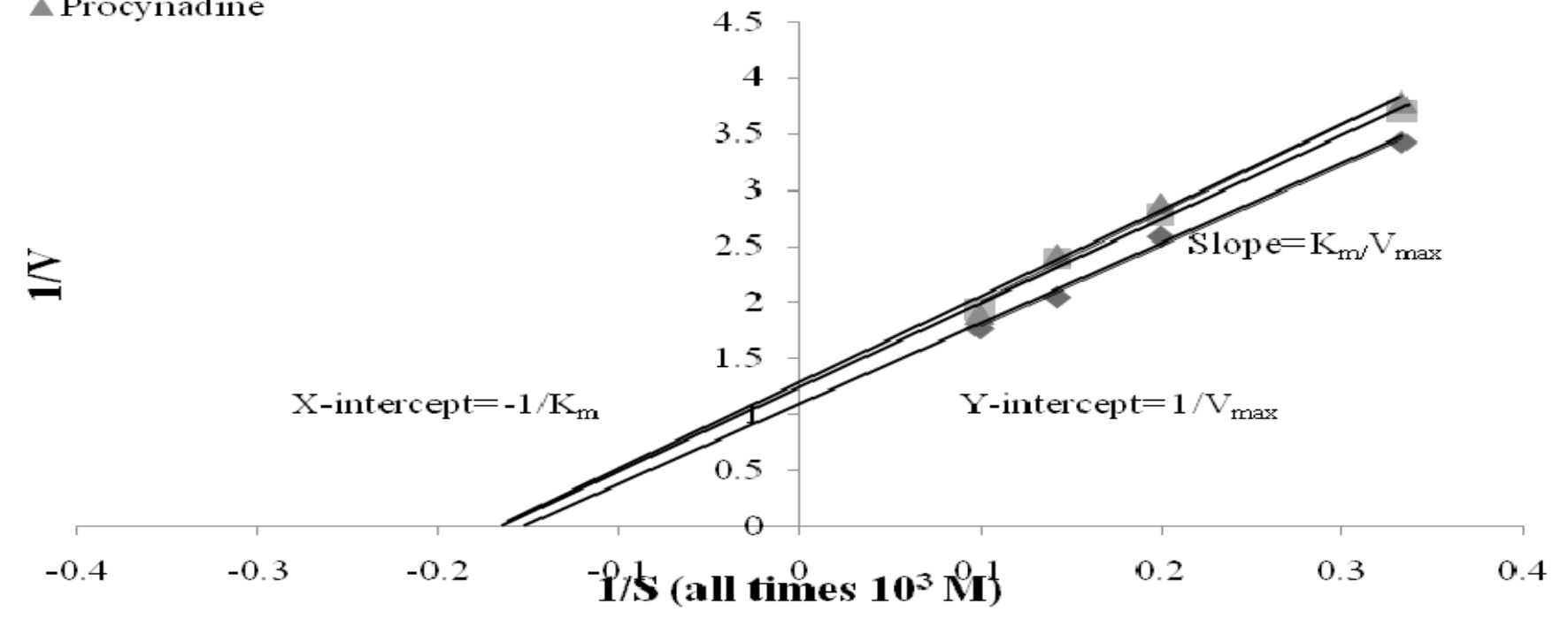

Figure 2: Lineweaver-burk plots showing the effects of column purified fraction and active component procynadine of T. indica seed ( $0.7 \mu \mathrm{g})$ on the inhibition acetylcholinesterase (AChE) activity in the cerebral ganglion of snail L. acuminata.. 


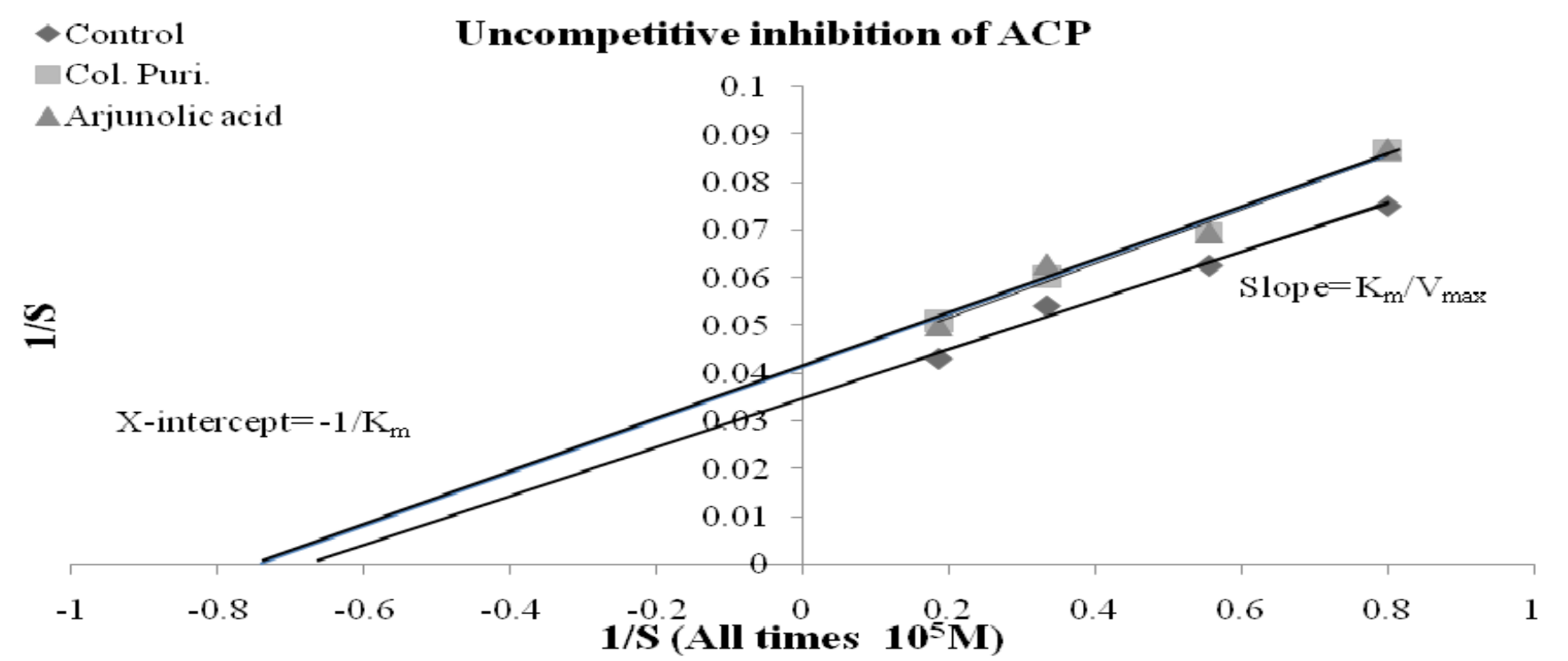

Figure 3: Lineweaver-burk plots showing the effects of column purified fraction and active component arjunolic acid of T. arjuna bark (5.0 $\mu \mathrm{g}$ ) on the inhibition acid phosphatase (ACP) activity in the cerebral ganglion of snail L. acuminata.

$\rightarrow$ Control

Col. Puri.

$\Delta$ Procynadine

\section{Competitive inhibition of $\mathrm{ACP}$}

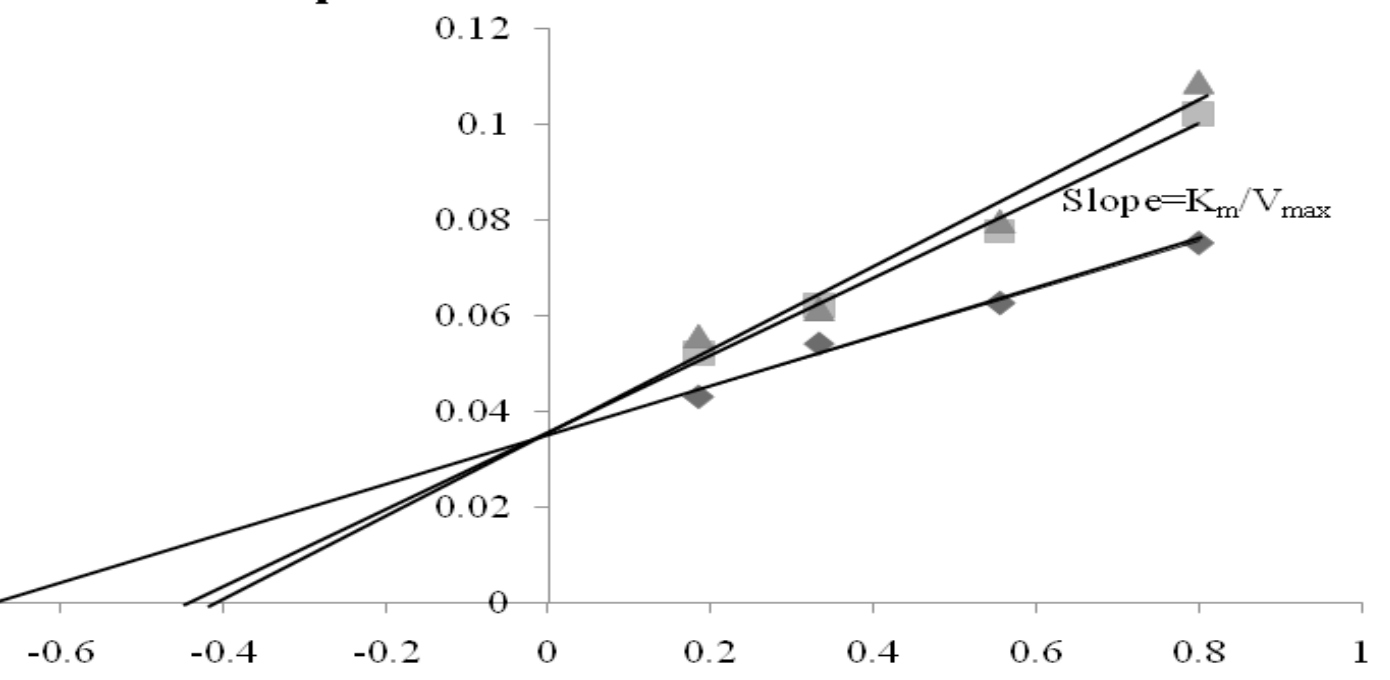

1/S (All times $10^{5} \mathrm{M}$ )

Figure 4: Lineweaver-burk plots showing the effects of column purified fraction (a) and active component procynadine (b) of $T$. indica seed ( $0.7 \mu \mathrm{g}$ ) on the inhibition acid phosphatase (ACP) activity in the cerebral ganglion of snail L. acuminata.

$23.25 \mu$ mole substrate hydrolyzed/30 $\mathrm{min} / \mathrm{mg}$ protein respectively (Fig $6)$.

\section{DISCUSSION}

Arjunolic acid and procynadine, active molluscicidal components of Terminalia arjuna bark and Tamarindus indica seed $^{13}$ caused significant inhibition of AChE, ACP and ALP activities in cerebral ganglion of Lymnaea acuminata in both in vivo and in vitro treatments. Maximum inhibition in AChE activity was noticed in cerebral ganglion of L. acuminata both in in vivo and in vitro treatment of procynadine. AChE is found in the synaptic membrane where it degrade the hydrolytic activity of the neurotransmitter acetylcholine, producing choline and acetate, a reaction important for the regulation of synaptic activity in central and peripheral neural system. ${ }^{21}$ AChE plays a significant role in nerve conduction process at myoneutral junction of nerve ending of muscle tissue. ${ }^{22}$ AChE inhibition caused accumulation of acetylcholine at the nerve synapses, so that the post synaptic membrane is in the state of permanent stimulation causing paralysis, ataxia, convulsion and death of animal. ${ }^{23,24,35}$ T. indica seed extract caused dose dependent inhibition of phaspholipase A and other enzyme activity of snake venom. ${ }^{25}$ Zhanq et $a l^{26}$ reported the in vitro cytotoxic effect of procynadine on human hepatoma G2 cell.

Arjunolic acid of T. arjuna caused maximum inhibition of ACP and ALP enzyme activity in the cerebral ganglion of L. acuminata. Bark extract of T. arjuna have significant reduction in marker enzymes alkaline phosphatase (ALP), acid phosphatase (ACP), alanin amino transferase (ALT), aspartate amino transfrase (AST), and lactate dehydrogenase (LDH) in serum, tissue of liver and kidney in alloxan induced diabetic rats. ${ }^{27}$ Arjunolic acid isolated from T. arjuna shows the cytotoxic activity against carcinoma and lymphoma cancer cell. ${ }^{28}$ Lysozyme enzyme ACP plays an important role in catabolism, pathological necrosis, autolysis and phagocytosis. ${ }^{29,30}$ Pilo et $\mathrm{al}^{31}$ reported the involvement of ALP play a 
Control

Col. Puri.

Arjunolic acid
Competitive-non-competitive inhibition of $\mathbf{A L P}$

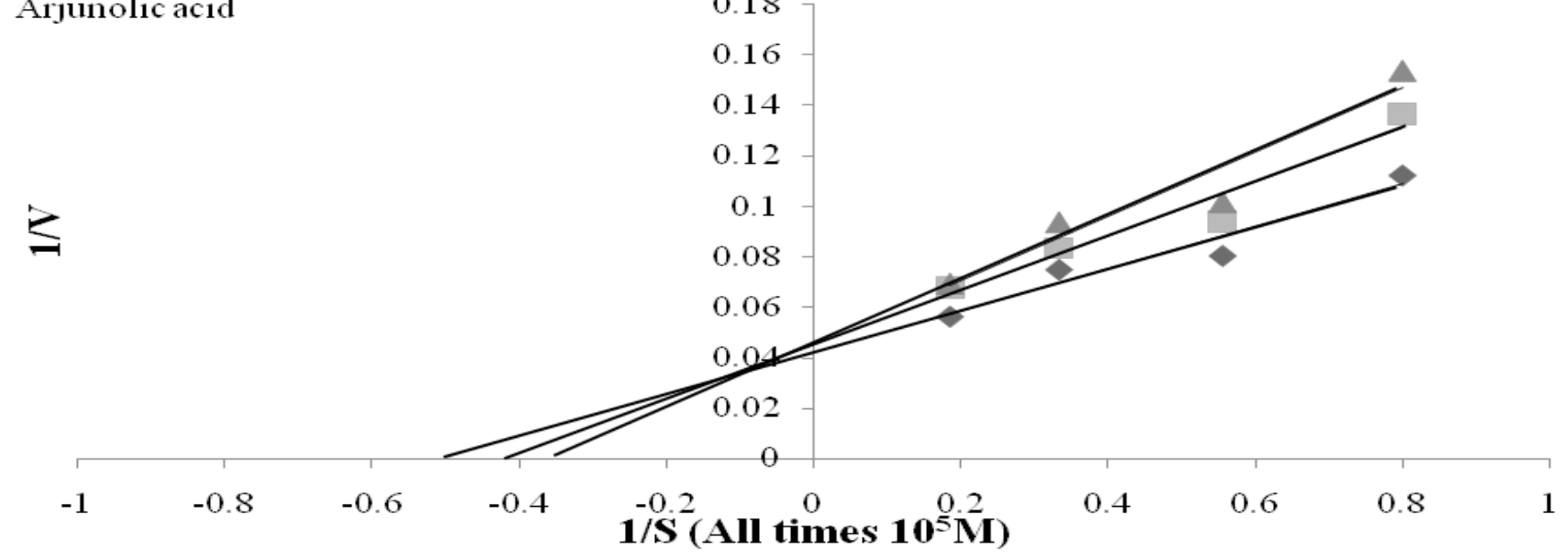

Figure 5: Lineweaver-burk plots showing the effects of column purified fraction and active component arjunolic acid of T. arjuna bark (5.0 $\mu \mathrm{g}$ ) on the inhibition of alkaline phosphatase (ALP) activity in the cerebral ganglion of snail L. acuminata.

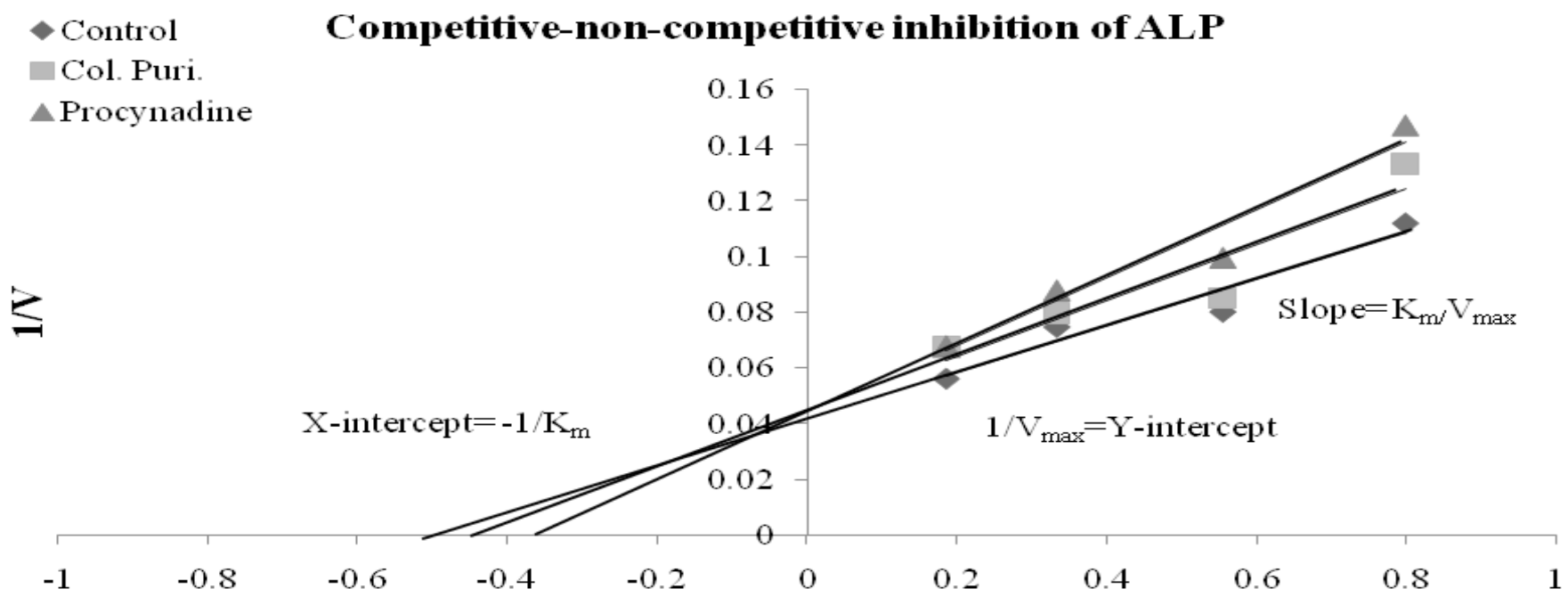

1/S (All times $10^{5} \mathrm{M}$ )

Figure 6: Lineweaver-burk plots showing the effects of column purified fraction and active component procynadine of $T$. indica seed ( $0.5 \mu \mathrm{g})$ on the inhibition of alkaline phosphatase (ALP) activity in the cerebral ganglion of snail L. acuminata.

critical role in protein synthesis, shell formation and other secretary activities in gastropods is noted by various workers. ${ }^{31,32,33}$ Decrease in ALP activity may result altered transport and inhibitory effect on cell growth and multiplication, reduction in protein level and severe acidosis. ${ }^{34}$

Kinetics result shows same Km value of inhibited and uninhibited enzymes and different $\mathrm{V}_{\max }$ on Lineweaver-Burk plots indicate that inhibition of AChE by column purified fraction and arjunolic acid of T. arjuna bark are non-competitive (Fig. 1). Slopes of inhibited and uninhibited AChE were not changed, both were parallel to each other, where as the intercept of inhibited and uninhibited AChE was changed that indicates column purified fraction and procynadine of T. indica seed caused uncompetitive inhibition in AChE activity (Fig.2). Slopes of inhibited and uninhibited ACP were not changed, both were parallel to each other, where as the intercept of inhibited and uninhibited ACP was changed that indicates column purified fraction and arjunolic acid of T. arjuna bark are non-competitive (Fig.3). Different Km value of inhibited and uninhibited enzymes and same $\mathrm{V}_{\max }$ on Lineweaver-Burk plots indicate that inhibition of ACP by column purified fraction of T. indica seed and procynadine was competitive (Fig. 4). Column purified fraction of T. arjuna bark and arjunolic acid and column purified fraction of T. indica seed and procynadine were competitive-non-competitive inhibition of ALP as $K_{m}$ and $V_{\text {max }}$ of uninhibited and inhibited enzyme were different and slope of inhibited and uninhibited enzyme were changed, it is a mixed type of inhibition. In this situation the plots cross to the left of the $1 / \mathrm{V}$ axis but above the $1 / \mathrm{S}$ axis (Fig. 5, 6). It was reported that different plant derived molluscicide caused different mode of inhibition in key enzymes AChE, ACP and ACP activities in the cerebral ganglion of $L$. acuminatea. ${ }^{35}$

\section{CONCLUSION}

It can be concluded that alteration of AChE, ACP and ALP activity by T. arjuna bark and T. indica seed and their active constituents in the cerebral ganglion of snail Lymnaea acuminata may be responsible their molluscicidal activity. 


\section{CONFLICT OF INTEREST}

We declare that we have no conflict of interest.

\section{ACKNOWLEDGMENTS}

We thankful to DDU Gorakhpur University for providing the research facility for complete the present paper.

\section{ABBREVIATIONS USED}

AChE: Acetylcholineastrase; ACP: Acid phosphates; ALP: Alkaline phosphates; CPF: Column purified fraction.

\section{REFERENCES}

1. Haridy FM, Morsy TA, Gawish TN, Abdel Gawad AG. The potential reservoir role of donkey and horses in zoonotic fasciolosis in Gharbia Governoret. J Egypt Soc Parasitol. 2002;32(2):561-70. PMid:12214933.

2. Mas-Coma S, Bargues, MD, Valero MA. Diagnosis of human fasciolosis by stool and blood techniques; update for the present global scenario. Parasitol. 2014;41(1):N1918-46. https://doi.org/10.1017/S0031182014000869 PMid:25077569.

3. Singh VK. Climate change, food scarcity and disease. J Nutr Food Sci. 2016;6:e123. doi:10.4172/2155-9600.1000e123. https://doi.org/10.4172/21559600.1000 e123.

4. Ahasan SA, Valero MA, Chawdhury EH, Islam MA, Islam ER, Mondal MMH, Peixoto RV, Brinde L, Panova M, Mas-Coma S. CIAS detection of Fasciola hepatica/F. gigantica intermediate forms in bovines forms Bangladesh. Acta Par asit. 2016;61 (2):267-77. https://doi.org/10.1515/ap-2016-0037 PMid:27078650.

5. Sunita K, Habbib M, Kumar P, Singh VK, Husain SK, Singh DK. Inhibition of acetylcholinesterase and cytochrome oxidase activity in Fasciola gigantica cercaria by phytoconstituents. Acta Trop. 2016;154:19-4. https://doi.org/10.1016/j. actatropica.2015.10.021 PMid:26536397.

6. Shanko K, Olgira W. Prevalence of study of ovine fasciolosis in Jima Rare District, Horo Guduru Wollega Zone, Oromia Regional State, Western Ethiopia Journal of Veterinary Science and Technology. 2016;4:277-81.

7. Magaji AA, Ibrahim K, Salihu MD, Saulawa MA, Mohammed AA, Musawa AI. Prevalence of fasciolosis in cattle slaughtered in Sokoto Metropolitan Abattoir Sokoto, Nigeria. Adv Epidem. Volume 2014. Article ID. 247258, 5 pages.

8. Nyindo M, Lukambagire A. Fasciolosis; An ongoing zoonotic Trematodes infection. Biomed Res Int. Volume 2015 Article ID786195 pages 8

9. Ramachandran J, Ajjampur S, Chandramohan A, Varghese GM. "Case of human fasciolosis in Indian: tip of the iceberg". J Postgrad Med. 2012;58(2):150-52 https://doi.org/10.4103/0022-3859.97180 PMid:22718061.

10. Walker SM, Makundi AE, Namuba FV. The distribution of Fasciola hepatica and Fasciola gigantica within southern Tanzania-constraints associated with the intermediate host. Parasitology. 2008;135(4):495-03. https://doi.org/10.1017/ S0031182007004076 PMid:18205983

11. Marston A, Hostettmann K. Antifungal, molluscicidal and cytotoxic compounds from plants used in traditional medicine. In "Biologically Active Natural Products" (Eds., K. Hostettmann and P. J. Lea). Clarendon Press, Oxford, 1987;65-3.

12. Hallett K., Atfeild A., Comber S. and Hutchinson T.H. Developmental toxicity of metaldehyde in the embryos of Lymnaea stagnalis (Gastropoda-Pulmonata) coexposed to piperonyl butoxide. Science of the Total Environment. 2016;543:3743. https://doi.org/10.1016/j.scitotenv.2015.11.040 PMid:26575636.

13. Soni N, Sngh VK. Molluscicidal activity of Tamarindus indica and Terminalia arjuna against Indoplanorbis exustus: A causative agent of Trematodiasis. Sci Agri. 2015;12:163-70

14. Upadhyay A, Singh VK, Singh DK. Characterization of molluscicidal component of Moringa oleifera leaf and Momordica charantia fruits and their modes of ac- tion in snail Lymnaea acuminata. Rev Inst Med Trop Sao Paulo. 2013;55(4):21519. https://doi.org/10.1590/S0036-46652013000400006.

15. Ghaly NS, Mina SA, Younis N. Schistomicidal and molluscicidal activities of two Junipers species cultivated in Egypt and the chemical composition of their essential oils. J Med Plant Res. 2016;10(5):47-3. https://doi.org/10.5897/ JMPR2015.5993.

16. Ellman GL, Courtney KD, Andres V, Featherstone RMA. New rapid colorimetric determination of acetylcholinesterase activity. Biochem Pharmacol. 1961;7(2):88-5 https://doi.org/10.1016/0006-2952(61)90145-9.

17. Bergmeyer UH. Methods of enzymatic analysis. Academic Press: New York 1967; 1129.

18. Singh DK, Agarwal RA. Toxocity of piperonyl butoxide carbaryl synergism on the snail Lymnaea acuminata. Int Rev Gesamten Hydrobiol. 1989;74(6):689-99. https://doi.org/10.1002/iroh.19890740610.

19. Lowry $\mathrm{OH}$, Rosenbrough NJ, Farr AL, Randall RJ. Protein measurement with the folin phenol reagents. J Biol Chem. 1951;193:265-75. PMid:14907713.

20. Sokal RR, Rohlf FJ. Introduction to Biostatistics. San Francisco: W.H. Freeman 1995;225-29.

21. Elersek T, Filipic M. Organophasphorus pesticides mechanism of their toxicity. Nat Inst Biol Slovenia. 2011;244-260:ISBN,978-953-307-531-0.

22. Cajaraville MP, Bebianno MJ, Blasco J. Porle C, Saresquete C, Viarengo A. The use of biomarker to assess the impact of pollution on coastal environment of the Iberian Peninsula: a practical approach. Sci Total Environ. 2000;247(2):29511. https://doi.org/10.1016/S0048-9697(99)00499-4.

23. Matsumura F. Toxicology of insecticides, 2nd Ed. Plenum Press, 1985. New York. https://doi.org/10.1007/978-1-4613-2491-1.

24. Kumar N, Singh VK. Effect of chlorophylline bait on acetylcholinesterase and cytochorme oxidase activities in the nervous tissue of Lymnaea acuminata with exposure of sunlight and red light. European J. Boil. Res. 2016;6(4):254-9.

25. Ushanandini S, Nagaruju S, Harish KK. The anti-snake venom properties of Tamarindus indica (Leguminosae) seed extract. Phytother. Res. 2007:20(10):851-8. https://doi.org/10.1002/ptr.1951 PMid:16847999.

26. Zhang $\mathrm{H}$, Ke J, Shao T, Duan $Y, H e Y$, Zhang C, Chen G, Sun X. Cytotoxic effect of procynadins from Castenea mollissima BI. Shell on human hepatoma $\mathrm{G} 2$ cell in vitro. Food Toxicol. 2014;64:166-76. https://doi.org/10.1016/j.fct.2013.11.026 PMid:24291453.

27. Ragavan B, Krishnakumri S. Effect of Terminalia arjuna stem bark extract on the activities of marker enzymes in alloxan induced diabetic rats. Anc Sci Life. 2005;25(1):8-5. PMid:22557182 PMCid:PMC3330897.

28. Moeshed MA, Uddin MA, Ahmed T, Uddin, F, Zakaria M, Haque A, Parvez AK. Evaluation of analgesic and anti-inflammatory activity of Terminalia arjuna ethanol extract. Int J Pharma Sci Res. 2011;11:2577-85.

29. Aruna P, Chetty CS, Naidu RC, Swami KS. Acid phosphatase activity in Indian ap ple snail Pilaglobosa (Swainson) during aestivation and starvation stress. Proc Ind Acad Sci. 1979;88(5):363-65. https://doi.org/10.1007/BF03179115.

30. Abou-Donia MB. Increased acid phosphatase activity in following an oral dose of Leptophos. Toxicol Lett. 1987;2(4):119-03.

31. Pilo B, Asnani MV, Shah RV. Studies on the wound healing and repair in pigeon. III: Histochemical studies on acid and alkaline phosphatase activity during the process. J Anim Morphol Physiol. 1972;19:205-12.

32. Timmermans LPM. Studied on the shell formation in mollusks. Nether J Zool. 1969:19:17-6

33. Ibrahim AM, Higazi MG, Demian E. Histochemical localization of alkaline phosphatase activity in the alimentary tract of the snail Mersa cornuarieties (L). Bul Zool Society Egypt. 1974;26:94-05.

34. Shaikila BJ, Thangavel $P$, Ramaswamy M. Adaptive trends in tissue acid and alkaline phosphatase of Sarotherodon mossambica (Peter) under sawin toxicity. Indian J Environ HIth. 1993;35(1):69-3.

35. Singh VK, Singh DK. Enzyme inhibition by allicin, the molluscicidal agent of Allium sativum L. (Garlic). Phytother Res. 1996;10(5);383-86. https://doi. org/10.1002/(SICI)1099-1573(199608)10:5<383::AID-PTR855>3.0.CO;2-9.

\section{ABOUT AUTHORS}

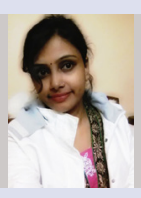

Neelam Soni, Research Scholar of Malacology Laboratory, Department of Zoology, DDU Gorakhpur University, Gorakhpur, UP, India. She completed her UG and PG from DDU Gorakhpur University, Gorakhpur and enrolled for her doctorate studied under the supervision of Dr. Vinay Kumar Singh. She is working on isolation, characterization and biological evaluation of natural products and pest control, vector-borne diseases from two years. 


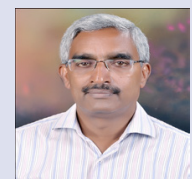

Professor D. K. Singh, Malacology Laboratory, Department of Zoology, DDU Gorakhpur University, Gorakhpur, UP, India has university teaching and research experiences of more than 32 years. Current research interests are toxicology and molluscan physiology. He has published 182 research papers, 14 review articles in 75 leading International Journals of repute with high impact factors. Dr. Singh publications have got 3019 citations all over world having $28 \mathrm{H}$-index and $87 \mathrm{i}-10 \mathrm{index}$ Prof Singh has produced $26 \mathrm{Ph} . \mathrm{D}$. and successfully conducted 15 research projects.

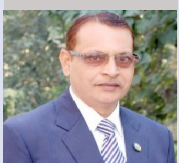

Dr. Vinay Kumar Singh, Assistant Professor stage-III, Department of Zoology, DDU Gorakhpur University, Gorakhpur, UP, India has university teaching and research experiences of more than 20 years. Current research interests are isolation, characterization and biological evaluation of natural products and pest control, vector-borne diseases. He has published 110 research papers, 10 review articles in 65 leading International Journals of repute with high impact factors. Prof Singh has produced 10 Ph.D. and successfully conducted 01 research projects. Dr. Singh publications have got 748 citations all over world having $16 \mathrm{H}$-index and $23 \mathrm{i}-10$ index. Dr Singh is serving as Editor-in-Chief of research J of Parasitology, USA. Dr. Singh was nominated as member of University Court (JNU) by Hon'ble President of India.

Cite this Article: Soni N, Singh DK, Singh VK. Inhibition Kinetics of Acetylcholinesterase and Phosphatases by the Active Constituents of Terminalia arjuna and Tamarindus indica in the Cerebral Ganglion of Lymnaea acuminata. Pharmacogn J. 2017;9(2):148-56. 